\title{
Røyking øker risikoen for demens
}

\section{Storrøyking midt i livet dobler sannsynligheten for demens 20 år senere, ifølge en prospektiv studie med over 21000 deltakere.}

En sammenheng mellom røyking og demens har vært kontroversiell. I en ny studie har man fulgt 21123 amerikanere over 23 år (1).

I løpet av studieperioden utviklet 5367 av deltakerne demens. Etter korrigering for en rekke bakgrunnsfaktorer hadde storrøykere

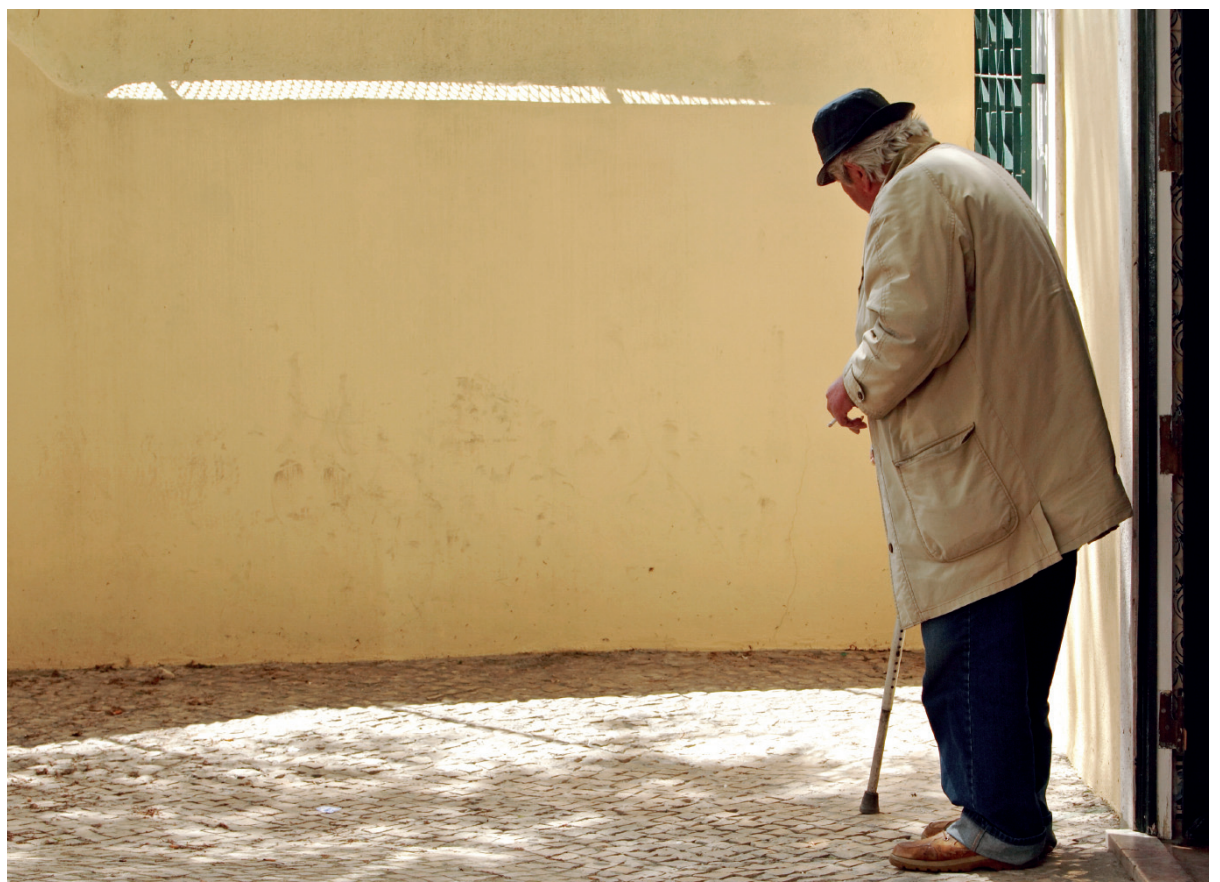

Illustrasjonsfoto Istockphoto over 20 år tidligere mer enn dobbelt så stor risiko for demens (justert hasardratio 2,14). Liknende tall ble funnet både for Alzheimers demens og vaskulær demens.

- Det er tidligere påvist en sammenheng mellom røyking og demens, men dette er første gang man har påvist at røyking midt i livet er assosiert med både Alzheimers sykdom og vaskulær demens sent i livet, sier professor Knut Engedal ved Nasjonalt kompetansesenter for aldring og helse, Oslo universitetssykehus. Studiens styrke er lang oppfølgingstid og at man har kontrollert for en rekke risikofaktorer for vaskulær sykdom.

- Svakheten ved studien er at man ikke har korrigert for beskyttende faktorer som mental og fysisk aktivitet. Det er ikke urimelig å tenke seg at storrøykere er mindre fysisk aktive, muligens også mindre mentalt aktive. Resultatene samsvarer med studier med kortere oppfølgingstid. Dette viser at røyking er ugunstig for kognitiv funksjon i høy alder, uansett hvilke mekanismer som ligger bak, sier Engedal.

\section{Are Brean}

are.brean@legeforeningen.no

Tidsskriftet

\section{Litteratur}

1. Rusanen M, Kivipelto M, Quesenberry CP et al. Heavy smoking in midlife and long-term risk of Alzheimer disease and vascular dementia. Arch Intern Med 2011; 171: 333-9.

\section{Ikke aksilletoalett}

\section{ved begrenset spredning til vaktpostlymfeknuter}

\section{I en amerikansk studie fant \\ man ingen overlevelsesgevinst \\ av aksilletoalett ved brystbevarende \\ operasjon for svulster under $5 \mathrm{~cm}$ \\ med spredning til to eller færre \\ vaktpostlymfeknuter}

Etter norske retningslinjer bør vaktpostlymfeknuteoperasjon utføres for pasienter med brystkreft i stadium T1 og T2 uten påviste lymfeknutemetastaser og ved duktalt carcinoma in situ (DCIS) grad 3, der det skal gjøres mastektomi. Hvis metastaser til vaktpostlymfeknuten påvises, eller hvis vaktpostlymfeknuten ikke kan lokaliseres, anbefales aksilletoalett (1).
I en amerikansk studie ble 891 brystkreftpasienter med spredning til to eller færre vaktpostlymfeknuter randomisert til brystbevarende operasjon og vaktpostlymfeknuteoperasjon med eller uten aksilletoalett (2). Overlevelsen for pasientene behandlet uten aksilletoalett var ikke dårligere enn pasientene som ble operert med aksilletoalett.

- Aksilletoalettets betydning ved brystkreft har vært omdiskutert, sier avdelingsoverlege Ellen Schlichting ved Avdeling for bryst- og endokrinkirurgi ved Oslo universitetssykehus. Tidligere ble aksilletoalett gjort hos alle pasienter med brystkreft, mens de siste ti år er aksilletoalett bare anbefalt ved spredning til vaktpostlymfeknutene.

Alle pasientene i denne studien fikk strålebehandling mot brystet, men ikke spesifikk aksillebestråling. Nesten alle pasientene fikk adjuvant systemisk behandling. Studien tyder på at selekterte pasienter med brystkreft og spredning til inntil to vaktpostlymfeknuter kan spares for aksilletoalett ved samtidig bruk av strålebehandling og systemisk behandling, sier Schlichting.

\section{Lars Frich}

lars.frich@legeforeningen.no

Tidsskriftet

\section{Litteratur}

1. Norsk Bryst Cancer Gruppe. Behandlingsanbefalinger 2011. www.nbcg.no/nbcg.blaaboka.html (21.2.2011)

2. Giuliano AE, Hunt KK, Ballman KV et al. Axillary dissection vs no axillary dissection in women with invasive breast cancer and sentinel node metastasis: a randomized clinical trial. JAMA 2011; 305 $569-75$. 